[Bull. Agr. Chem. Soc. Japan, Vol. 24, No. 1, p. 105 111, 1960]

\title{
Radioactive Contamination of Milk and Milk Products in Japan
}

\author{
By Rinjiro Sasaki, Tomokichi Tsugo, Susumu Koyama, \\ Tatsuo SATo and Yoichiro OMOMo \\ Department of Agricultural Chemistry, Facully of Agricullure, \\ University of Tokyo \\ Received May 19, 1959
}

\begin{abstract}
Radioactive contamination of milk and milk products in Japan was studied extensively. Samples were collected monthly or every season from several districts of Japan.

In this report, total radioactivity of raw milk and skim milk powder and strontium-90 (Sr-90) concentration of skim milk powder and sweetened condensed milk were measured. These experiments show that there is neither seasonal variation nor regional variation in total radioactivity, and that in the measurements of $\mathrm{Sr}-90$ concentration the values in northern districts are higher than those in other parts of Japan.
\end{abstract}

\section{INTRODUCTION}

On account of nuclear fission products born out of nuclear weapon tests, there is an increasing tendency in the radioactive contamination upon air, rain water, soil, cereals, vegetables, farm animals and their products from year to year.

Among nuclear fission products, Sr-90 and cesium-137 (Cs-137) which have long half-lives are said to be the most dangerous elements for human body. Sr-90, as well as calcium, belongs to the alkaline-earth metals, and, therefore, its chemical properties resemble to those of calcium. In this respect, it is reasonable to expect that strontium behaves similarly as calcium in biological processes when it enters into the human body.

Europeans and Americans usually take their calcium mainly from milk and milk products, while Japanese take chiefly from vegetable foods. But recently the consumption of milk and milk products in Japan has gradually been accelerated year by year. Especially, artificial-feeding infants take their nutrition mainly from milk and milk products. Therefore it is of significance to investigate the radioactive contamination in milk and milk products in Japan.

For this purpose, the measurements of total radioactivity in raw milk and skim milk powder and concentration of $\mathrm{Sr}-90$ in skim milk powder and sweetened condensed milk were carried out accordingly.

\section{EXPERIMENTAL}

I. Total radioactivity in raw milk and skim milk powder

\section{(1) Samples}

Raw milk and skim milk powder which were collected monthly from June 1956 to May 1957 from 41 and 17 localities respectively were used for radioactivity assay. But occassionally when skim milk powder was not manufactured in some localities, whole milk powder was used for assay instead of skim milk powder.

(2) Measurement of radioactivity

(a) Ashing of samples

Raw milk: $180 \mathrm{ml}$ of raw milk were measured into a beaker, evaporated in boiling water, transferred to a crucible, heated two hours in a crucible type electric furnace until a carbonaceous mass was obtained, and then transferred to a muffle furnace and heated below $550^{\circ} \mathrm{C}$ until a white ash was obtained.

Skim milk powder : $25 \mathrm{~g}$ of skim milk powder (in case of whole milk powder $20 \mathrm{~g}$ was used) were weighed out into a crucible, and then treated in the same way as mentioned in the ashing of raw milk. 
(b) Measurement of radioactivity: About $0.5 \mathrm{~g}$ of ash was weighed out into a counting tray, $25 \mathrm{~mm}$ in diameter and $6 \mathrm{~mm}$ in depth, manufactured by the Physical and Chemical Research lnstitute.

After leveling the surface of ash with a glass rod having a flat end, it was weighed accurately, and then the radioactivity was measured with Model 32-G Geiger Müller counter tube manufacture by the Physical and Chemical Research Institute. The radioactivity was expressed as cpm per $1 \mathrm{~g}$ of ash. The time required for

TABLE I. TOTal Radioactivity OF Raw MILK (cpm/g of Ash)

\begin{tabular}{|c|c|c|c|c|c|c|c|c|c|c|c|c|}
\hline & ocality & Number & $\begin{array}{l}1956 \\
\text { June }\end{array}$ & July & August & September & October & November & December & $\begin{array}{l}1957 \\
\text { January }\end{array}$ & February & May \\
\hline Hokkaido & & A 1 & 45 & 48 & 46 & 47 & 48 & 45 & 48 & 36 & 39 & 47 \\
\hline "l & & B 2 & & 56 & 40 & 49 & 45 & 44 & 46 & 46 & 54 & 52 \\
\hline 11 & & C 3 & 42 & 47 & 45 & 46 & 51 & 45 & 47 & 39 & 50 & 47 \\
\hline$\prime \prime$ & & D 4 & & 50 & 44 & 51 & 40 & 46 & 48 & 30 & 40 & 49 \\
\hline$\prime \prime$ & & E 5 & 54 & 47 & 46 & 43 & 46 & 41 & 45 & 40 & 40 & 39 \\
\hline 11 & & 6 & 41 & 53 & 41 & 53 & 52 & 46 & 44 & 43 & 42 & 45 \\
\hline$n$ & & G 7 & 44 & 51 & 44 & 36 & 49 & 48 & 50 & 44 & 46 & 48 \\
\hline Tôhoku & Iwate & 8 & 52 & & 51 & 45 & 43 & 53 & 49 & 40 & 38 & 37 \\
\hline$\prime \prime$ & Miyagi & 9 & 51 & 47 & 45 & 46 & 46 & 45 & 47 & 40 & 52 & 52 \\
\hline$\prime \prime$ & Yamagata & A 10 & 45 & 51 & 46 & 46 & 49 & 47 & 49 & 33 & 45 & 39 \\
\hline$\prime \prime$ & II & B 11 & & 49 & 42 & 46 & 46 & 44 & 46 & 41 & 35 & 39 \\
\hline$" 1$ & Fukushima & 12 & 41 & 54 & 45 & 23 & 44 & 48 & 46 & 45 & 46 & 42 \\
\hline Kanto & Tochigi & 13 & 42 & 57 & 42 & 49 & 44 & 49 & 48 & 44 & 44 & 37 \\
\hline 11 & Gunma & 14 & 48 & 47 & 46 & 45 & & 43 & 45 & 49 & 35 & 40 \\
\hline$\prime \prime$ & Ibaragi & 15 & 45 & 49 & 41 & 45 & 50 & 48 & 49 & 36 & 36 & 39 \\
\hline$\prime \prime$ & Saitama & 16 & 49 & 50 & 42 & 43 & 48 & 45 & 48 & 50 & 40 & 30 \\
\hline$\prime \prime$ & Tôkyo & 17 & 49 & 43 & 49 & 48 & 43 & 50 & 40 & 43 & 46 & 23 \\
\hline$\prime \prime$ & Chiba & 18 & 51 & 57 & 47 & 46 & 49 & 51 & 48 & 60 & 53 & 38 \\
\hline$\prime \prime$ & Kanagawa & 19 & 45 & 40 & 49 & 43 & 52 & 48 & 50 & 39 & 46 & 42 \\
\hline Chûbu & Niigata & 20 & 51 & 48 & 48 & 46 & 46 & & 47 & 52 & 42 & 36 \\
\hline "I & Nagano & A 21 & 45 & 46 & 33 & 48 & 40 & 39 & 40 & 44 & 34 & 41 \\
\hline$\prime \prime$ & II & B 22 & 48 & 47 & 45 & 43 & 47 & 47 & 46 & 35 & 41 & 40 \\
\hline$\prime \prime$ & Ishikawa & 23 & 57 & 48 & 45 & 49 & 48 & 45 & 47 & 35 & 46 & 74 \\
\hline$\prime \prime$ & Yamanashi & A 24 & 45 & 53 & 43 & 44 & 45 & & 46 & 41 & 47 & 42 \\
\hline$\prime \prime$ & $\prime \prime$ & B 25 & 48 & 47 & 42 & 41 & 37 & & 43 & 39 & 50 & \\
\hline$\prime \prime$ & Shizuoka & 26 & 52 & 54 & 38 & 44 & 46 & 45 & 46 & 40 & 46 & 50 \\
\hline$\prime \prime$ & Aichi & 27 & 49 & 45 & 45 & 45 & 48 & 43 & 45 & 42 & 48 & 52 \\
\hline Kinki & Kyôto & 28 & & 47 & 48 & 47 & 49 & 47 & 48 & 44 & 40 & 39 \\
\hline 11 & Ôsaka & A 29 & 48 & & 40 & 42 & 44 & 46 & 45 & 41 & 45 & \\
\hline$\prime \prime$ & "I & B 30 & 50 & 51 & 43 & 44 & 44 & 45 & 47 & 43 & 45 & 43 \\
\hline$\prime \prime$ & Hyôgo & A 31 & & 47 & 42 & 46 & 45 & 40 & 45 & 44 & 42 & 52 \\
\hline - & "I & B 32 & & 51 & 39 & 43 & 46 & 55 & 50 & 51 & 54 & 42 \\
\hline Chûgoku & Tottori & 33 & & 61 & 45 & 44 & 47 & 48 & 46 & 40 & 54 & 51 \\
\hline "I & Okayama & A 34 & 46 & 53 & 42 & 44 & 43 & 49 & 47 & 35 & 53 & 42 \\
\hline$\prime \prime$ & $/ 1$ & B 35 & & 50 & 38 & 43 & 53 & & 50 & 25 & 55 & 38 \\
\hline " & Yamaguchi & 36 & 48 & 47 & 38 & 43 & 46 & 44 & 46 & 48 & 46 & 50 \\
\hline Shikoku & Tokushima & 37 & 52 & & 45 & 47 & 45 & 46 & 46 & 55 & 50 & 49 \\
\hline$\prime \prime$ & Ehime & 38 & & 49 & 36 & 49 & 55 & 47 & 48 & 40 & 46 & 42 \\
\hline Kyûshû & Saga & 39 & 51 & 46 & 43 & 46 & 47 & 48 & 50 & 35 & 47 & 51 \\
\hline$\prime \prime$ & Kumamoto & 40 & 54 & 56 & 53 & 46 & 49 & 51 & 50 & 55 & 58 & 60 \\
\hline$\prime \prime$ & Kagoshima & 41 & & 46 & 40 & 41 & 47 & & 46 & 44 & 38 & 44 \\
\hline
\end{tabular}


Table II. Total Radioactivity of Skim Milk Powder (cpm/g of Ash)

\begin{tabular}{|c|c|c|c|c|c|c|c|c|c|c|c|c|c|c|}
\hline \multicolumn{2}{|c|}{ Locality } & \multicolumn{2}{|c|}{ Number } & $\begin{array}{l}1956 \\
\text { June }\end{array}$ & July & August & Septenber & October & November & Dacember & $\begin{array}{l}\text { 1957 } \\
\text { January }\end{array}$ & February & April & Ma \\
\hline Hokkaido & & A & 1 & & 46 & 39 & 53 & 45 & 51 & 46 & & & 50 & 36 \\
\hline$\prime \prime$ & & $B$ & 2 & 44 & 45 & 38 & 41 & 47 & 40 & & 26 & 33 & & \\
\hline$\prime \prime$ & & C & 3 & 46 & & & & 45 & 47 & & & & & \\
\hline$" 1$ & & $\mathrm{D}$ & 4 & 49 & 49 & 49 & 50 & 45 & 40 & 31 & 41 & 42 & & \\
\hline Tôhoku & Iwate & & 5 & 47 & 41 & 41 & 41 & $4 \mathrm{I}$ & 46 & & & & 48 & \\
\hline "I & Yamagata & $\mathrm{A}$ & 6 & 40 & 46 & 44 & 43 & 44 & & 50 & & & 42 & \\
\hline "l & & B & 7 & 53 & 58 & 44 & 54 & 55 & 40 & & & 46 & 43 & \\
\hline Kantô & Kanagawa & & 8 & 50 & 50 & 43 & 47 & 50 & 42 & 43 & & 40 & & \\
\hline Chûbu & Nagano & A & 9 & 41 & & 38 & 51 & 38 & 49 & 45 & 40 & 40 & & \\
\hline$\prime \prime$ & "I & $\mathrm{B}$ & 10 & 43 & & 48 & 49 & 41 & 50 & 44 & 42 & & 46 & \\
\hline$\prime \prime$ & "l & $\mathrm{C}$ & 11 & 49 & 59 & 38 & 54 & 49 & 47 & 48 & 39 & & & \\
\hline$n$ & Yamanashi & & 12 & & 47 & 48 & 47 & 50 & 45 & 44 & & & & \\
\hline$\prime \prime$ & Shizuoka & A & 13 & 48 & 45 & & & & & & 41 & 39 & 38 & \\
\hline$" 1$ & "I & B & 14 & & & & & 41 & 40 & & & & 42 & \\
\hline Kinki & Hyôgo & A & 15 & 49 & 50 & 45 & & & & 40 & & & & \\
\hline "I & "I & B & 16 & 46 & & & 43 & 43 & 50 & 48 & 44 & & & \\
\hline Chûgoku & Okayama & & 17 & 45 & 46 & & & 43 & 50 & 47 & 43 & & & \\
\hline
\end{tabular}

counting was one hour both in background and in samples. The results are shown in Tables I and II.

\section{Measurement of $\mathrm{Sr}-90$ concentration in skim} milk powder and sweetened condensed milk

\section{(1) Samples}

Skim milk powder (or in certain cases whole milk powder) collected from six districts every season (August, October in 1957, February, May in 1958) was used for the measurement of Sr-90 concentration. Besides these, sweetened condensed milk and skim milk powder manufactured before 1957 and 1956 respectively were also used for assay. But in the case of the latter, four kinds of skim milk powder collected from four districts were mixed in proportion to the output of each district, and then this mixture was submitted to assay.

(2) Separation procedure of $\mathrm{Sr}-90$ and the measurement of radioactivity

(a) Outline of separation procedure: In the same way as discribed in Experimental I, the samples were burnt to ashes below $650^{\circ} \mathrm{C}$.

$100 \mathrm{~g}$ of ash were generally used for this assay, but in the case of the samples which contained Sr-90 in comparative large quantity, $20 \sim 50 \mathrm{~g}$ were used.

As to separation procedure, the nitric acid method, having been originated in Noll's method") and improved by Asari $^{2)}$, was adopted.

1) W. Noll, Z. Anorg. Chem., 199, 193 (1931).

2) T. Asari and H. Watanabe, Reports of the Pbysical and Chemical Research Institute, 23, 402 (1944).
Outline of this method is as follows. Carrier-free sample was dissolved in dilute fumic nitric acid. This solution was bolled and filtered. The filtrate was evaporated in order to remove chlorine gas. After cooling, fumic nitric acid ( $d=1.52)$ was added, and this solution was allowed to stand overnight, and filtered through sintered glass funnel. The precipitate obtained was dissolved in hot water and filtered. After the filtrate was evaporated, fumic nitric acid $(d=1.52)$ was added. The solution was filtered as before. This procedure was repeated two or three times.

The precipitate was dissolved in hot water and evaporated below $100 \mathrm{ml}$. $1.5 \mathrm{M}$ sodium chromate and ammonia were added to this solution. Then the solution was adjusted $\mathrm{pH} 5.5 \sim 6.0$ with acetic acid, heated at $90^{\circ} \mathrm{C}$, and filtered. After the filtrate was evaporated below $100 \mathrm{ml}$, ammonium acetate and barium carrier (barium chloride) were added. The solution was heated at $90^{\circ} \mathrm{C}$, and filtered as before. The procedure was repeated once again. By this procedure barium and radium were separated from calcium and strontium.

Ammonia and excess of ammonium carbonate were added to the filtrate. The solution was boiled and filtered. The precipitate obtained was dissolved in dilute nitric acid and evaporated to dry up. The residue was dissolved in small amount of water and to this solution fumic nitric acid was added until the specific gravity became just 1.45. By this procedure only strontium nitrate was precipitated. The precipitate was dried and 
108 Rinj̈ro Sasaki, Tomokichi Tsugo, Susumu Koyama, Tatsuo SATo and Yoichiro Omomo

Table III. Sr-90 Concentration of Skim Milk Powder oR Whole Milk Powder

\begin{tabular}{|c|c|c|c|c|c|c|c|c|c|}
\hline $\begin{array}{l}\text { Kind } \\
\text { of } \\
\text { Sample }\end{array}$ & & Locality & Date & & $\mathrm{Ca} \%$ in ash & $\mathrm{Sr} / 100 \mathrm{Ca}$ & $\begin{array}{c}\mathrm{Sr}^{90} \mu \mu \mathrm{c} / \mathrm{g} \\
\text { of } \mathrm{Ca} \\
\text { (S.U.) }\end{array}$ & $\begin{array}{c}\mathrm{Sr}^{90} \mu \mu \mathrm{c} / 7 \mathrm{mg} \\
\mathrm{Sr} \\
\text { (M.U.) }\end{array}$ & $\begin{array}{c}\mathrm{Sr}^{00} \mu \mu \mathrm{c} / \mathrm{kg} \\
\text { of } \\
\text { Sample }\end{array}$ \\
\hline Skim & Hokkaido & & August & 1957 & 14.4 & 0.038 & $4.3 \pm 0.4$ & 79.4 & 50.1 \\
\hline$\| \prime$ & II & & October & "l & 14.6 & 0.033 & $5.2 \pm 0.5$ & 110.0 & 63.8 \\
\hline$" \prime$ & $\prime \prime$ & & January & 1958 & 14.7 & 0.062 & $6.7 \pm 1.5$ & 76.5 & 82.2 \\
\hline$\prime \prime$ & "I & & May & $\prime \prime$ & 14.7 & 0.032 & $4.2 \pm 0.97$ & 86.9 & 48.1 \\
\hline Whole & Tôhoku & Miyagi & August & 1957 & 15.0 & 0.030 & $1.2 \pm 0.1$ & 28.0 & 10.5 \\
\hline Skim & $\|$ & Yamagata & October & /I & 13.5 & 0.036 & $2.0 \pm 0.2$ & 39.4 & 21.7 \\
\hline Whole & $" \prime$ & $\prime \prime$ & January & 1958 & 15.4 & 0.023 & $0.9 \pm 0.06$ & 28.5 & 8.8 \\
\hline$\prime \prime$ & $\prime \prime$ & $\prime \prime$ & May & $\prime \prime$ & 13.2 & 0.027 & $1.7 \pm 0.85$ & 44.2 & 13.8 \\
\hline$\prime \prime$ & Kanto & Gunma & October & 1957 & 15.1 & 0.021 & $1.1 \pm 0.2$ & 35.5 & 10.1 \\
\hline Skim & " & "l & January & 1958 & 14.5 & 0.041 & $1.4 \pm 0.3$ & 24.0 & 17.1 \\
\hline$\prime \prime$ & $\prime \prime$ & "I & May & $\prime \prime$ & 14.8 & 0.024 & $1.0 \pm 0.2$ & 29.8 & 12.4 \\
\hline Whole & Chûbu & Yamanashi & August & 1957 & 15.7 & 0.031 & $1.5 \pm 0.2$ & 34.8 & 13.9 \\
\hline$\prime \prime$ & $\prime \prime$ & Nagano & October & 11 & 14.9 & 0.034 & $1.2 \pm 0.1$ & 25.4 & 11.1 \\
\hline$\prime \prime$ & $" 1$ & $\prime \prime$ & January & 1958 & 14.4 & 0.046 & $2.2 \pm 0.3$ & 33.0 & 19.6 \\
\hline$\prime \prime$ & "I & " & May & $\prime \prime$ & 14.6 & 0.033 & $0.8 \pm 0.3$ & 15.8 & 6.7 \\
\hline$\prime \prime$ & Kinki & Hyôgo & August & 1957 & 14.0 & 0,026 & $1.3 \pm 0.3$ & 35.9 & 11.6 \\
\hline Skim & $\prime \prime$ & "l & October & $\prime \prime$ & 14.5 & 0.025 & $0.61 \pm 0.12$ & 17.3 & 7.6 \\
\hline 11 & $\prime \prime$ & $\|$ & January & 1958 & 14.5 & 0.041 & $1.0 \pm 0.25$ & 17.4 & 12.5 \\
\hline 11 & \multirow{2}{*}{\multicolumn{2}{|c|}{$\begin{array}{l}\text { Chûgoku and Shikoku, } \\
\text { Tokushima }\end{array}$}} & May & $n$ & 15.1 & 0.019 & $0.5 \pm 0.1$ & 16.4 & 5.8 \\
\hline$\prime \prime$ & & & August & 1957 & 13.6 & 0.022 & $1.2 \pm 0.2$ & 36.2 & 13.9 \\
\hline$\prime \prime$ & " & 11 & October & $\prime \prime$ & 14.3 & 0.041 & $1.4 \pm 0.3$ & 23.2 & 16.6 \\
\hline 11 & "l & $\prime \prime$ & January & 1958 & 14.9 & 0.024 & $1.6 \pm 0.25$ & 45.4 & 19.6 \\
\hline$\prime \prime$ & $/ \prime$ & $m$ & May & $" 1$ & 13.5 & 0.031 & $1.0 \pm 0.5$ & 22.3 & 11.2 \\
\hline
\end{tabular}

Table IV. Sr-90 Concentration of Sweetened Condensed Milk

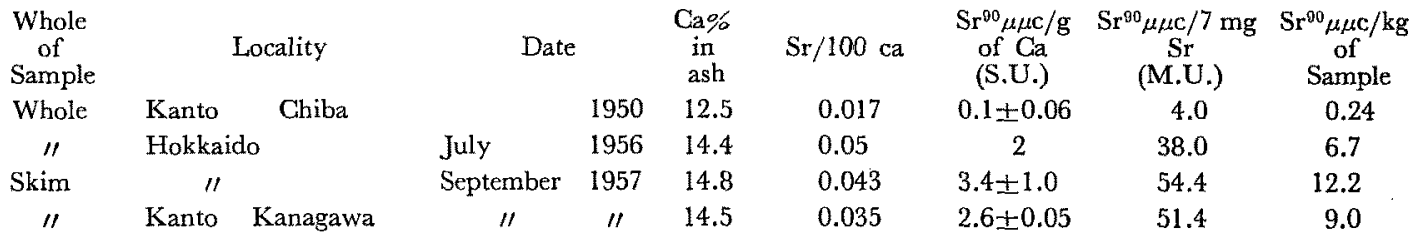

Table V. Sr-90 Concentraticn of Skim Milk Powder

\begin{tabular}{|c|c|c|c|c|c|c|c|}
\hline $\begin{array}{l}\text { Kind } \\
\text { of } \\
\text { Sample }\end{array}$ & Locality & Date & $\begin{array}{l}\text { Ca\% } \\
\text { in } \\
\text { ash }\end{array}$ & $\mathrm{Sr} / 100 \mathrm{Ca}$ & $\begin{array}{l}\mathrm{Sr}^{90} \mu \mu \mathrm{c} / \mathrm{g} \\
\text { of } \mathrm{Ca} \\
\text { (S.U.) }\end{array}$ & $\begin{array}{c}\mathrm{Sr}^{00} \mu \mu \mathrm{c} / 7 \mathrm{mg} \\
\mathrm{Sr} \\
\text { (M.U.) }\end{array}$ & $\begin{array}{c}\mathrm{Sr}^{90} \mu \mu \mathrm{c} / \mathrm{kg} \\
\text { of } \\
\text { Sample }\end{array}$ \\
\hline Skim & $\left\{\begin{array}{l}\text { Hokkaido } \\
\text { Yamagata } \\
\text { Ishikawa } \\
\text { Hyôgo }\end{array}\right.$ & $\left\{\begin{array}{l}1951 \\
1952 \\
1953\end{array}\right\}$ & 14.0 & 0.018 & $0.054 \pm 0.03$ & 2.1 & 0.65 \\
\hline Skim & $\left\{\begin{array}{l}\text { Hokkaido } \\
\text { Yamagata } \\
\text { Ishikawa } \\
\text { Hyôgo }\end{array}\right.$ & 1956 & 14.4 & 0.07 & 2.1 & 21.0 & 2.2 \\
\hline
\end{tabular}


weighed. After weighing, the strontium nitrate was converted to carbonate, and then submitted to counting.

This strontium carbonate was left for two or three weeks until radiation equilibrium was obtained between Sr-90 and Y-90, and then dissolved in hydrochloric acid. To this solution ferric chloride was added as carrier for measurement of yttrium, and carbonic acid free water saturated with ammonia was added. Yttrium was precipitated as yttrium hydroxide and this precipitate was submitted to counting.

(b) Measurement of radioactivity : Radioactivity was measured at the Yamazaki Laboratory of the Physical and Chemical Research Institute. The results are shown in Tables III, IV and V.

Sr-90 concentration in samples is given as $\mathrm{Sr}-90 \mu \mu \mathrm{c} / \mathrm{g}$ of $\mathrm{Ca}$ (S. U., Sunshine Unit). And, in addition, SY-90 $\mu \mu \mathrm{c} / \mathrm{kg}$ of sample was calculated for convenience.

\section{DISCUSSION}

\section{Total radioactivity}

It was found that there was scarcely any difference in the total radioactivity between raw milk and skim milk powder. The values shown in Tables I and II were averaged monthly as shown in Table VI. of radioactivity.

As a result, the radioactivity of potassium chloride showed $118 \mathrm{cpm}$ per $1 \mathrm{~g}$. If all of the radioactivity of potassium chloride is originated in potassium, the radioactivity of potassium will be $226 \mathrm{cpm}$ per $1 \mathrm{~g}$. As to potassium sulfate, the same result was obtained. Further, it was shown by $\mathrm{Nakae}^{3)}$ that the content of potassium in milk ash was averaged $0.21 \mathrm{~g}$ per $\mathrm{lg}$ of ash. From these results, consequently, it is recongnizable that the radioactivity of potassium in $1 \mathrm{~g}$ of milk ash become about $48 \mathrm{cpm}$.

Bergh $^{4}$ showed that most biological materials contained appreciable $\mathrm{K}-40$ activity, in case of milk 3000 $5000 \mathrm{dpm}$ per liter. In authors' experiment, $40 \sim 50 \mathrm{cpm}$ per $\mathrm{lg}$ of ash is converted to $2400 \sim 4000 \mathrm{dpm}$ per 1 liter of milk.

Putting all these results together, it is considered that most of the radioactivity in milk would originate in natural radioactive substances, especially such as $\mathrm{K}-40$.

It is considered that this is the reason why neither seasonal variation nor regional variation

TABle VI. TOTAL Radioactivity AVERAged MONTHLY

\begin{tabular}{|c|c|c|c|c|c|c|c|c|c|c|}
\hline Kind of Sample & $\begin{array}{r}\text { Date } 1956 \\
\text { June }\end{array}$ & July & August & September & October & November & December & $\begin{array}{l}1957 \\
\text { January }\end{array}$ & February & April \\
\hline Raw milk & 48 & 50 & 44 & 45 & 47 & 46 & 47 & 42 & 45 & - \\
\hline Skim milk powder & 46 & 47 & 43 & 48 & 45 & 46 & 45 & 40 & 40 & 44 \\
\hline
\end{tabular}

Table VI shows that seasonal variation in total radioactivity is hardly found in both raw milk and skim milk powder. And also regional variation is hardly noticeable in Table I and II.

From these results, it is reasonable to expect that most of the radioactivity in milk could be attributed to natural radioactive substances and therefore variation in radioactivity owing to artificial radioactive substances, if any, hardly affects the total radioactivity.

In order to ascertain this, simple experiment was carried out. $0.5 \mathrm{~g}$ of potassium chloride, which was commonly used as reagent in chemical analysis, was weighed out into counting tray and its radioactivity was measured in the same way as mentioned in the measurement in total activity was found in this experiment.

\section{II. $\mathrm{S} \mathbf{r}-\mathbf{9 0}$ concentation}

Table III shows that Sr-90 concentration in skim milk powder is higher in the northern districts of Japan than in the central or southern districts and the highest in Hokkaido.

A report from the Japan Meteorological Agency ${ }^{53}$ showed that the accumulative amount of Sr-90 (presumtive value) was higher in Hokkaido and Tohoku (the north-east district of Honshu) than on the Pacific side of Japan. It

3) T. Nakae, Bulletin of the National Institute of Agriculiural Sciences, Japan. No. 36 (1938).

4) H. Bergh, A Method for the Determination of Very Small Amounts of $I-131$ in Biological Materials, Expecially in Milk A/ CONF. 15/P/586, Norway, 28 May, 1958.

5) The present condition of observation of artificial radioactivity in Japan, March 1958: Reports of Japan Meteorological Agency. 
is considered that this is one of the reasons why Sr-90 concentration in skim milk powder is higher in Hokkaido or in the north-east. Besides, the condition of feeding cows is considered as another reason.

In Hokkaido the grazing of cows is practised extensively, while in the other districts of Japan cows are usually fed in stalls. In case of grazing, there are more frequent occasions that cows directly take grass which is contaminated by radioactive rain water and directly exposed to radioactive rain water or dust than in case of feeding in a stall. Therefore it is considered that the milk produced in Hokkaido contains more $\mathrm{Sr}-90$ than that in the other districts of Japan.

A report from the United National General Assembly ${ }^{6)}$ showed that the average Sr-90 concentration in milk produced in six stations of Canada was 5.0 S.U. in 1956 and 6.2 S.U. in 1957. These are similar values in Hokkaido, but are much higher than in the other districts of Japan. And the same report showed the average Sr-90 concentration in milk produced in New York City was 3.9 S.U. in 1956 (from January to May) and 4.5 S.U. in 1957 (from January to August) and, further, average Sr-90 concentration in milk produced in Mandan was 9.2 S.U. in 1956 and 9.3 S.U. in 1957 (from January to July).

From above, it is recognized that Sr-90 concentration in milk is higher in Mandan than Hokkaido.

A report from West Germany ${ }^{\text {? }}$ showed that the rate of radioactive contamination on milk produced in West Germany was similar to that in the United States of America and Canada, and that the averages Sr-90 concentration in milk was $4 \sim 5$ S.U. in 1956 .

Putting these data together, it is conclusively evident that the milk produced in Japan is less contaminated by Sr-90 than in Canada, the United Siates of America and West Germany.

6) United Nations General Assembly, Scientific committee on the effects of atomic radiation, The effects of atomic radiation, A/AC. 82/R. 65/Add. 38 May 1958.

7) Physikalisches Institut der Bundesforschungsanstalt für Milchwirtsschaft, Kiel, Private communication (1958).
On the other hand, summarizing all results (shown in Tables III, IV and V) it is recognizable that the radioactive contamination on condensed milk and skim milk powder has shown an increasing tendency in its accumulation for the past decade in Japan. For instance, the Sr-90 concentration in condensed milk manufactured in 1956 is twenty times as high as that 1950.

But, in comparison with other foodstuffs, Radiological Data in Japan $\mathrm{II}^{8}$ showed that the Sr-90 concentration in milk and milk products was much lower than in vegetables, tea, soybean and rice. Vegetables and cereals are directly contaminated by radioactive substances, while milk is filtered by passing through the cow's body. This is the reason why Sr-90 concentration in milk and milk products is lower than that in vegetables and cereals.

Table III shows that there is some seasonal variation in $\mathrm{Sr}-90$ concentration, but judging merely from the results obtained, it is not possibie to say about the relation between seasonal variation and atomic weapon test. As to this point, further investigations are required.

In order to account for the fact that Sr-90 concentration in skim milk powder manufactured in Hokkaido is higher than that in the other districts of Japan, it is necessary to investigate the Sr-90 concentration in food-stuffs, rain water and soil near the milk products factory in detail.

\section{SUMMARY}

Raw milk and skim milk powder collected monthly from several districts in Japan (from June 1956 to May 1957) were burnt to ashes and their total radioactivities were measured.

As a result, total radioactivities showed 40 $50 \mathrm{cpm}$ per $1 \mathrm{~g}$ of ash. There was neither seasonal variation nor regional variation in the total radioactivity.

Skim milk powder (or whole milk powder) collected every season from six districts in Japan

8) Y. Hiyama, Radiological Dita in Japan II. Concentrations of $\mathrm{Sr} \cdot 90, \mathrm{Cs}-137, \mathrm{Pu}-239$ and others in various materials on earth's surface. Sept. 1958. 
(August, October in 1957, Fubruary, May in 1958) was burnt to ashes and its $\mathrm{Sr}-90$ concentration was measured.

Results obtained showed that $\mathrm{Sr}-90$ concentration in skim milk powder manufactured in the northern districts were higher than those in the central or southern districts of Japan.

The Sr-90 concentrations are as indicated in the following districts.

Hokkaido

: $4.2 \sim 6.7 \mathrm{Sr}-90 \mu \mu \mathrm{c} / \mathrm{g}$ of $\mathrm{Ca}$

Tohoku

Kanto
$: 0.9 \sim 2.0 \quad$ "

$: 1.0 \sim 1.4 \quad$ "I
Chubu

Kinki

$: 0.8 \sim 2.2$

$: 0.5 \sim 1.3$

Chugoku and Shikoku: $1.0 \sim 1.6$

The authors wish to thank Dr. Yamazaki and Mr. Hashizume, Physical and Chemical Research Institute, for having taken charge of counting in the measurement of Sr-90 concentration, and to Dr. Asari, Japan Inspection Co. Ltd., for his valuable counsel and good offices given in the measurement of Sr-90 concentration. 